\title{
Response to Quigley ${ }^{1}$
}

\author{
Ann Brower
}

I warmly thank the editor for the opportunity to reply. I shall highlight three technical differences between Professor Quigley's and my positions, then conclude with the major theoretical difference.

1) Professor Quigley cites no statute, case law, or legal theory supporting his interpretation of the law. He states that a pastoral runholder may 'acquire the freehold rights' at the end of a lease's term. By contrast, the law firmly establishes the Crown as the ultimate owner of Crown land (Page and Brower 2007). The Land Act 1948 s. 66(2) and the Crown Pastoral Land Act 1998 s. 4(c, d) state that the runholder has 'no right to the soil; and no right to acquire the fee simple of any of the land.'

2) Professor Quigley argues that tenure review is a nationalization because more land is conserved than privatised. Though Professor Quigley describes farmers as 'giving up' high country land to transfer into conservation, farmers give up grazing rights not land. It is incorrect to describe tenure review as a nationalization because the Crown owned all the land before the review, and owns less than half ${ }^{2}$ after the review. It is a partial shift in land use and property rights, from pastoralism to conservation, but not a nationalization. However it is correct to say that land passing from Crown ownership to private ownership is privatized.

3) Professor Quigley argues that the results reported in Brower, Meguire, and Monks (in review) are artifacts of the construction of the dependent variable. In preparing that paper, we experimented with several dependent variables, including the straight ratio which he prefers. According to an economic interpretation of property as a bundle of rights and tenure review as an exchange of property rights, a scatterplot of each dependent variable we tried should yield a horizontal line. No matter the algebra of the dependent variable, every scatterplot revealed a diagonal; hence our results are robust.

4) Finally, Professor Quigley and I appear to differ over a point of basic economics regarding the values exchanged in tenure review. He argues, as others have (Armstrong et al 2007: paragraph 19.6), that the option to develop newly privatised land should not influence prices paid in tenure review, because the Crown cannot exercise the development option whilst the land is under lease. Hence the development option has no value in the exchange (Evans and Quigley 2006: 3).

By contrast, Adam Smith argued in The Wealth of Nations that a good might be useless to the current owner yet still command a high selling price because the purchaser thinks it would be useful.

The things which have the greatest value in use have frequently little or no value in exchange, and on the contrary, those which have the greatest value in exchange have frequently little or no value in use. Nothing is more useful than water: but it will purchase scarce any thing; scarce any thing can be had in exchange for it. A diamond, on the contrary, has scarce any value in use; but a very great quantity of other goods may frequently be had in exchange for it. (Smith 1776: chapter 4) (emphasis added)

The runholder's pastoral rights are like Smith's water; the development option is like the diamond. To argue

1 I gratefully acknowledge the contribution of my colleagues Philip Meguire and Adrian Monks and the helpful suggestions of the reviewer. This research was funded by Fulbright-New Zealand and Lincoln University.

2 To 2008, tenure review runholders have acquired title to 270,082 hectares, and the Crown shifted 196,728 hectares from pastoralism to conservation. Hence $58 \%$ of tenure review land has been privatised. 
that the development option is irrelevant is to assume that the value in use equals the value in exchange. Microeconomics posits that this is rarely true, if ever (Hirshleifer et al 2005: chapters 3-5). ${ }^{3}$

The Crown may have no immediate use for the development option, but advertised land prices around Queenstown and Wanaka suggest that the development option has a high value in use to the new landowners. Hence freehold land in the high country should command a high value in exchange, and the Crown's selling price should be high. Until 2007, the Crown's generosity towards pastoral runholders in tenure review was difficult to reconcile with Smith's reasoning.

\section{References}

Armstrong, D. J., R. L. Engelbrecht, and R. L. Jefferies. (2007) High Country Pastoral Leases Review 2005 2007: A Review of Pastoral Lease Rental and Tenure Review Valuation Methodologies and Outcomes Associated with Pastoral Lands Throughout the South Island of New Zealand, in Wellington, NZ: Land Information New Zealand.

Brower, A., P. Meguire, and A. Monks. (in review) Closing the Deal: Principals, Agents, and Sub-Agents in New Zealand Land Reform.

Evans, L. and N. Quigley. (2006) A Review of Ann Lacey Brower "Interest Groups, Vested Interests, and the Myth of Apolitical Administration: The Politics of Land Tenure Reform on the South Island of New Zealand". Rakaia, New Zealand: High Country Accord. Found at http://www.highcountryaccord. co.nz/downloads/Evans-Quigley_Report.pdf (viewed 29 February 2008)

Hirshleifer, J., A. Glazer, and D. Hirshleifer. (2005). Price Theory and Applications: Decisions, Markets, and Information (7th Ed.). New York Cambridge University Press.

3 Put another way, if a hypothetical Sam owns a titanium bicycle then suffers an incurable wrist injury which renders him unable to cycle ever again, the bicycle ceases to have a positive value in use. But this does not mean that Sam should give the bicycle away, or pay someone to take it away, as the Crown has often done under tenure review. Either course of action would be far more generous than Smith's discussion would predict, because a titanium bicycle's value in exchange is unaffected by the cycling abilities of its current owner. Because Sam will never ride it again, he may be willing to sell it for less than an avid cyclist would. This would lower, but not extinguish, its value in exchange.
Page, J., and A. Brower. (2007). Property Law in the South Island High Country -- Statutory, Not Common Law Leases. Waikato Law Review. 15: 48-63.

Smith, Adam, (1982) The Wealth of Nations Books I-III. New York: Penguin Classics.

Ann Brower is a lecturer in public policy at Lincoln University. She specializes in natural resource policy, and the intersection between law, economics and politics. 